\title{
Legal Aid Scheme In Indonesia: Between The Policy And The Implementation
}

\author{
Elisabeth Sundari \\ Fakultas Hukum Universitas Atma Jaya Yogyakarta \\ Jl. Mrican Baru 2855281 Yogyakarta \\ sundayustitia@yahoo.co.id
}

\begin{abstract}
In the legal policy level, the government of Indonesia has already had the policies to assist the justice seekers who are financially weak to have an access to justice through court. There are two research problems in this matter. First, does the policy on the legal assistance as stipulated in Law Number 16 of 2011 work optimally for the justice seekers who are financially weak? Second, how is the implementation of the policy on the legal assistance in the practices? The normative research was conducted to answer those two questions, through document data such as Law No.48 of 2009 on The Principles of Justice Power, Law No. 8 of 2003 on Advocate, and Law No. 16 of 2011 on Legal Assistance, and the implementation of those regulations in the practices in several places. The conclusion obtained from the research is: First, it is not yet optimum since the policy especially in terms of budget allocation of the legal assistance is still low. The professional lawyers tend to avoid their obligation to free give legal assistance to the poor. Second, in practice, the legal assistance is not yet enjoyed by the poor justice seekers. The economic and good will are the influencing factors.
\end{abstract}

Key words : Legal assistance, justice, budget allocation

\begin{abstract}
Abstrak
Pada tingkat kebijakan hukum, Pemerintah Indonesia telah memiliki kebijakan untuk membantu para pencari keadilan yang tidak mampu secara ekonomi untuk memperoleh akses keadilan melalui peradilan. Terdapat dua permasalahan hukum yang dapat ditemukakan. Pertama, apakah kebijakan bantuan hukum sebagaimana diatur dalam UU Nomor 16 Tahun 2011 memberi hasil yang optimal bagi pencari keadilan yang tidak mampu secara ekonomi? Kedua, bagaimana implementasi dari kebijakan bantuan hukum tersebut dalam praktek? Penelitian normatif dilakukan untuk menjawab permasalahan tersebut, melalui data dokumen berupa UU No.48 Tahun 2009 tentang Pokok-Pokok Kekuasaan Kehakiman, UU Nomor 8 Tahun 2003 tentang Advokat, dan UU Nomor 16 Tahun 2011 tentang Bantuan Hukum, serta implementasi dari peraturan-peraturan tersebut dalam praktek di beberpa tempat. Kesimpulan yang diperoleh dalam penelitian ini adalah pertama, belum optimal, karena kebijakan, khususnya alokasi anggaran bantuan hukum kecil. Pengacara profesional cenderung menghindar dari kewajibannya memberi bantuan hukum secara cuma-cuma kepada warga miskin. Kedua, dalam praktek bantuan hukum belum sepenuhnya dinikmati oleh warga miskin pencari keadilan. Faktor ekonomi dan kehendak baik merupakan faktor-faktor yang mempengaruhi.
\end{abstract}

Kata kunci : Bantuan bukum, keadilan, alokasi anggaran 


\section{Background}

Legal aid policy in Indonesia has been around since the enactment of the HIR (Het Herziene Indonesisich Reglement) 1941. ${ }^{1}$ Article 237 HIR or 273 Rbg (Reglement Buiten Gewijsten) set of litigants who cannot afford the cost of the case for free of charge (pro deo). Those provision is one form of legal aid policy for those who economically can't access to justice through the courts.

Recently, Indonesian Government concern to assist poor litigants' access to justice. Rule 56(2) of the Fundamental of the Judiciary Power Act, No 48 of 2009 (Ind) provides that: 'The government bears the court costs for poor litigants'. In r57 of Act, No 48 of 2009 (Ind) stated: (1) Legal aid office is set up in every original court for litigants who cannot afford legal assistance; (2) Legal assistance referred to in paragraph (1) provided at no charge at all levels of the judiciary until the decisions on the matter has obtained the permanent legal force; (3) Legal assistance and legal aid office referred to in paragraph (1) carried out in accordance with the related regulation.

Those provisions are provided similarly to all levels, including general and limited jurisdiction. ${ }^{2}$ Based on r56(2) and r57 of Act No 48 of 2009 (Ind), the government has the legal aid scheme, including not only contributing to but also undertaking court costs for poor litigants and/or giving legal assistance for no charge.

Again, in 2011, the Indonesian Government issued the Legal Aid Act, No 16 of 2011. R6(2) of Act No 16 of 2011 also provides that legal aid carried out by the Government, and will be instructed to the Legal Aid Institution in accordance with the Act. With the recent legal policy on legal aid, it is expected that the legal aid for the poor litigants will be more optimum. Optimum means that it can provide the best results for the intended target. ${ }^{3}$

\footnotetext{
${ }^{1}$ The concept of legal aid- in the sense of giving assistance, the power or advocacy for the poor- can be said to begin institutionalized since the establishment of the Legal Aid (Adnan quoted, History of Legal assistance in Indonesia: Legal Aid, Access to Justice for Marginal Society, the Jakarta Legal Aid Jakarta, 2007, p.5).

${ }^{2}$ See, r68B \& 69C of Act No 49 of 2009 (the Second Amandement of Act No 2 of 1986 on the General Court, Ind); r60B \& 60C of Act No 50 of 2009 (the Second Amandement of Act No 7 of 1989 on the Religion Court, Ind); r144C \& 144D of Act No 51 of 2009 (the Second Amandement of Act No 5 of 1986 on the Administrative Court, Ind).

${ }^{3}$ The meaning of the term 'optimum' was taken from WJS Poerwadarminta, Indonesian Language Dictionary, Balai Pustaka, 1996, p.687.
} 


\section{The Legal Problem}

Based on the background, it can be decribed two legal problems. First, whether the legal aid policy as set out in the Act No 16 of 2011 will provide access to justice for the poor optimumly. Second, how is the implementation of that policy in practices.

\section{The Goal of the Research}

First, to explain whether the legal aid policy as set out in the Act 16 of 2011 will provide access to justice for the poor optimumly; Second, to describe the implementation of that policies in practices.

\section{The Method of the Research}

This research is a normative legal research. The main data is a documentary data which were compiled from legal policies concerning with legal aid scheme in Indonesia, as provided in Act, No 48 of 2009, in Act No.8 of 2003 on Advocate, and Act No 16 of 2011 on Legal Aid, and the implementation of those legal policies in some situation and some places, such as in Yogyakarta province, in Jakarta Province, in Sleman General Jurisdiction, and Yogyakarta General Jurisdiction Court. The samples are chosen on the consideration of comparing the condition between metropolitan city (Jakarta) and a general city (Yogyakarta Province).The data were analized qualitatively and were concluded deductively.

\section{The Data and Analizing}

\section{Part One. Optimizing Legal Aid Through the Policy}

Access to justice is a part of human rights, which could be inferred from the provisions in r7, r8 and r21(2) of the Universal Declaration of Human Rights 1948 (UDHR). ${ }^{4}$ Access to justice through the right to obtain legal assistance free of charge

${ }^{4}$ Article 7 UDHR: "All are equal before the law and are entitled without any discrimination to equal protection of the law. All are entitled to equal protection againts any discrimination in violation of this declaration or againts any incitement to such discrimination". Article 8 UDHR: "Every one has the right to an effective remedy by the competent of national tribunals fot acts violating the fundamental rights granted him by the constitution or by law". R21 (2) UDHR: "Every one has the right to equal access to public service to bis country". 
for those who can not afford, is also a part of human rights, as can be interpreted from the provision in r14.3.d of International Covenant on Civil and Political Rights (ICCR). Indonesian Constitution 1945 admit it well, which could be interpreted from the provision in $\mathrm{r} 28 \mathrm{D}(1)$ of the Indonesian Constitution 1945 (Second Amandment), that states: "Everyone has the right to recognition, security, protection, and fair legal certainty and equal treatment before the law".

One of the principles in the protection of human rights is, the State responsibility. It is the State that must hold protection rights of its citizens. That principle is consistent with the concept of the welfare state. ${ }^{5}$ Welfare state and state responsibility principles in the implementation of human rights are shared by Indonesia, which could be seen in the fourth paragraph of Preambule of Indonesian Constitution 1945 and the provisions in r28(4) of the Indonesian Constitution 1945 (second amandement). Fourth Paragraph of Indonesian Constitution 1945 principally states: “... The Government of Indonesia shall protect all the Indonesian people and the entire country of Indonesia and to promote the general welfare, the intellectual life of the nation, and participate in the establishment of a world order based on freedom, abiding peace and social justice ..." R28(4) of the 1945 Constitution (Second Amendment) states: "The protection, promotion, enforcement and fulfillment of human rights is the responsibility of the state, especially the government". Based on that provisions, the expectation of access to justice for the poor as part of human rights is, by optimizing access to justice through legal aid for the poor economically or structurally, by the State as responsible for the protection, promotion, enforcement, and compliance of human rights.

Based on legal aid purpose as set out in r3a and c of Act No 16 of 2011, access to justice can be optimized if it can be enjoyed equally well and by all poor people who need it. Most or all of the poor have access to justice properly if: the State provide facilities and infrastructure that supports the achievement of such access, such as: 1 . Open access widely to the poor people who need legal aid; 2 . Strong and coordinative institutional; 3. Sufficient funding; 4. target or goal based management in providing legal aid.

Act No 16 of 2011 is expected to provide optimum results for the intended target. However, it turns out that there are some shortcomings of the Act No 16 of 2011,

${ }^{5}$ See John Locke's ideas about the state of law with the motto: salus populi suprema lex esto, translated as: the state must preserve its citizens' rights (Theo Huijbers, Philosopby of Law in Track History, Canisius Publisher, Yogyakarta, 1982, p.81-82. 
which could hamper the efforts to optimize access to justice for the poor. Here is the explanation.

\section{The scope of legal aid which can be accessed}

Consideration part of Act No 16 of 2011, specify b states: "That. countries are responsible for the provision of legal aid to the poor ...". Considerations Part specify $\mathrm{C}$ states: "That the legal aid arrangements organized by the State should be oriented to the realization of a just social change". R5 of Act 16 of 2011 basically provides that legal aid recipients are persons or group of persons who can not meet their basic rights, like the right to food, clothing, health services, education services, employment and housing. From those provisions, it can be interpreted that Indonesian Government wishes to provide legal aid for the poor, both economically and structurally, because the orientation is the creation of 'equitable social change' and the target is the citizen who can not meet the basic rights, including the public service. ' A just social change' is part of the structural or social justice, which is the target of legal aid for the poor structurally.

On the other part, the provisions in r4(2) and r14(1)c of Act No 16 of 2011, can be interpreted to mean that the orientation of legal aid which would be built by the Act No 16 of 2011 is only legal aid for the poor people economically. R4 (2) limits the scope of the legal problems that can be requested for legal aid, namely the civil law issues, criminal and administrative. It does not include public service issues or constitutional law issue. For instance, the problem of access or injustice in the public service policies for the poor. Yet, precisely the legal aid for the poor structurally is the one that can realize an equitable social change as mandated by the preamble letter c. R14(1)c of Act No 16 of 2011 which determines that legal aid services to obtain legal aid recipients must attach the letter from the Village Head or equivalent official at the applicant's residence, clearly emphasizing the notion of 'poor' as the poor economically. From the scope of legal aid as set forth in r4, and r5 of Act No16 of 2011 gives less attention to the provision of legal aid for the poor structurally, ${ }^{6}$ who face legal problems, namely social injustice or structural injustice. The scope of legal aid in the Act No 16 of 2011 thus, is less than optimal in providing access to justice for the poor structurally. Moreover, the structural or social injustice faced by the

\footnotetext{
${ }^{6}$ If it should not be said as not giving access or attention.
} 
poor in general is done by the government that has the duty to enforce social or structural justice for its citizens.

The scope of legal aid in the Act No 16 of 2011 is also limited to consulting and legal services by lawyers or other legal aid officer, and does not include a "litigants on a pro deo" for those who can not afford the cost of the case. The policy of free of charge in litigation actually has been known since the enactment of the HIR (r237) and $\mathrm{Rbg}$ (r273) and reinforced by the provisions in r56(2) of Act No 48 of 2009, which states that the State bears the cost of the case for the poor who can not afford.

Under the Act No 48 of 2009 the budget for legal aid is allocated through the Supreme Court budget. Under the provisions in r22 of Act No 16 of 2011 should the free of charge litigation policy still there, while the budget can be allocated through the Government (i.e the Ministry of Justice and Human Rights) budget. It turns out that within the scope of legal aid under the Act No 16 of 2011, the program would be lost. The Act No 16 of 2011 then causes the existence of "a free of charge litigation" policy becomes unclear. That limited scope of legal aid, makes access to justice through the provision of legal assistance becomes less optimum.

The mandatory legal aid in criminal justice was also not accommodated by the Act No 16 of 2011. R56 of the Criminal Procedure Code, Act No 8 of 1981 requires law enforcement officers to inform the suspect or the accused and pointed defender to assist them free of charge if: a. The offenses alleged or charged is punishable by death or lifetime imprisonment, without looking at the economic background of the suspects or accused; $b$. The suspect or the accused have the poor background economically and are suspected criminal offenses or charged that is punishable by imprisonment for five years or more.

In the model of the mandatory legal aid in Act No 8 of 1981, recipients do not need to apply for legal aid as well as become a model in Act No 16 of 2011, because Act No 8 of 1981 requires State to give legal assistance freely eventhough the suspected or accused does not apply the legal assitance.

\section{The Institutions in the administration of legal aid}

The implementation of legal aid in Act No 16 of 2011 was only involves three institutions, namely both central and local government, as well as the legal aid institutes, and the verification and certification committee of legal aid institutes. The central government serves as a provider of fund, the supervisor and the assessor. 
Local Government serves as a provider of fund, but optionally. Verification and certification committee is an institution established by the Government to function as a legal aid assessors.

In the existing institutional elements, Act No 16 of 2011 does not mention the role of law enforcement officers in the administration of legal aid, including the presence of Legal Aid Post. The absence of the element of the law enforcement officers due to the duality of authority for legal aid. The creators of Act No 48 of 2009 enter legal assistance as part of the law enforcement process, so that it is entranced into the judicial power held by the Supreme Court as well as the original and apellate courts.

Since the organization of the judicial power technically, organizationally and financially is under the Supreme Court (based on Act No 48 of 2009), SEMA No.10 of 2010 as the implementation of Act No 48 of 2009, requires that financial administration of legal aid falls in the budget of the Supreme Court.

Instead, the creators of Act No 16 of 2011 considers that the provision of legal aid programs entered as a part of the provision of public services, which is the task of the Government (i.e the Ministry of Justice and Human Rights). Then, the implementation of the legal aid budget falls in the budget of the Ministry of Justice and Human Rights. Under the transitional provisions of r22 of Act No 16 of 2011, the organization and the legal aid budget done by the Supreme Court, the prosecutor and the police remain in effect until the end of the fiscal year in question. Under the provision in r22 of Act No 16 of 2011, the implementation of legal aid will be taken over by the Executive, both in implementation and budgeting. The principle question: Is it not contrary to the new paradigm of the independence of judicial power as mandated by Indonesian Constitution 1945 and Act No 48 of 2009 which state that the judicial power is technically and organizationally is under the Supreme Court? Who then set the law enforcement authorities in connection with the implementation of legal aid in court proceedings?

R54-55 of Act No 8 of 1981 stipulates the rights of the suspect or the accused to obtain legal aid. No further provisions governing the exercise of these rights. In practice, the investigator or the prosecutor or judges often do not notify the suspect or the accused about the existence of such rights, because there is no provision that requires law enforcement officials to notify the existence of such rights. The rights of the suspect or the accused to obtain legal aid then could be lost due to their ignorance 
and none of them were informed their rights. Eventhough he was notified, no further provisions about how the suspect or the accused may obtain the right to legal aid, who will give, where to look for it, wether the legal aid free of charge or not, and so on.

The law enforcement officials are required to notify the suspect or the accused and appoint legal counsel to provide legal assistance free of charge in terms of: ${ }^{7}$ a. The offenses alleged or charged is punishable by death or lifetime imprisonment, without looking at the economic background of the suspects or defendants; $b$. The suspect or defendant have the poor background economically and are suspected criminal offenses or charged that is punishable by imprisonment for five years or more.

The Act 16 of 2011 makes no mention of how the technical implementation of legal aid in more detail at the level of investigation, prosecution, courts of first instance, appeal and cassation.

Losses that were clearly experienced significantly due to changes in the legal beneficiary organization of the legal aid authority are: a. The existence of legal aid post as newly initiated by the Supreme Court to assist justice seekers who can not afford, becomes unclear; b. Legal aid programs by way of a free of charge litigation was no more element in the legal aid scheme which actually should be enjoyed by litigants.

Act No 48 of 2009 and SEMA No.10 of 2010 as operating regulations provides that in any court of original jurisdiction, whether the general jurisdiction courts, religious courts or administrative courts, will be set up Legal Aid Post for poor litigants who can not afford, and will provide legal assistance in free of charge. The implementation of legal assistance through Legal Aid Post has somewhat a different and more detailed requirements and procedures than the way the organization of legal aid as set out in Act No 16 of 2011.

The provision of legal assistance through Legal Aid Post engaged the Chairman of the original Court to provide space for the Legal Aid Post, establish a picket advocate that working with legal aid institute,who will provide legal assistance, appoint a professional advocate to provide legal assistance free of charge (pro bono) which will obtain legal aid assistance fund. Legal aid as meant by the creators of Act No 16 of 2011 can be provided by: ${ }^{8}$ a. Legal aid institution; or b. social organization

\footnotetext{
${ }^{7}$ See the provisions of $\mathrm{r} 56$ of Act No 8 of 1981

${ }^{8}$ See the provisions of $\mathrm{r} 7$ (1) b
} 
Both must be an incorporated. The creators of Act No 16 of 2011 will not provide funding for legal aid if it held by individual. What might a professional advocate be appointed by the judge to assist defendants who face the death penalty? Act No 16 of 2011 has less emphasisment or encouragement for individual advocates to carry out their obligations to provide legal aid in free of charge, as mandated in r22(1) of Advocates Act, No 18 of 2003. There is no provision in the Act No 16 of 2011 about how the free of charge legal aid by professional lawyer who appointed by the judge in the criminal case be implemented. However, providing legal aid requires effort, thought and time. The funding support then will give the spirit for the professional lawyers to do so in accordance of their obligations.

The encouragement for individual advocates to provide legal assistance in free of charge is actually going to support the optimization of the quality in giving the legal aid for the poor. Litigants are not only entitled to legal assistance in free of charge, but should at the same time the access be granted in a professional manner. Do not grant the legal aid into the low quality, just because it was given for free of chrage.

\section{Providing legal aid budget}

In management, budget support is one important element to support the achievement of the goal. Horngren and Foster argued that budget and performance report are very helpful in evaluating whether the target is achieved. ${ }^{9}$ The goal can not be separated from policy and strategic plan. The strategic plan further embodied in the targets set out in the work program. The work program elaborated and realized in the form of money that was expressed in terms of budget. Javanese proverb also says: Jer Basuki Mowo beyo, which means that to achieve the safety, efficacy, desired objectives, requires effort, including the cost of. The existance of legal aid budget, will support the fulfillment of the rights of the poor to obtain access to justice, ${ }^{10}$ as part of human rights and as the ultimate goal.

Since the budget is an important element in achieving the goal, then the lack of budget will influence the achievement of optimum goal. In r3c of Act No 16 of 2011 stated that the purpose of the law is to ensure that the provision of legal aid certainty

\footnotetext{
${ }^{9}$ Charles T Horngren, Cost Accounting: A managerial Emphasis, Firth Edition. Englewood Cliffs: Prentice-Hall, Inc.,1982, hal.172.

${ }^{10}$ See the provisions of r3a of Law No.16 of 2011.
} 
held evenly in all regions of the country of Indonesia. In order to achieve the goal, the budget allocation for the legal aid programs to support the implementation of the law should be sufficient. How was the allocation of budget in legal aid scheme?

The Act No 16 of 2011 mandates that legal aid program is implemented by the Minister. ${ }^{11}$ Consequently, the Government (i.e the Ministry of Justice and Human Rights) is also responsible to provide or allocate budget to support its implementation. The primary source should come from the government budget. According to the Act No 16 of 2011, the source of the legal aid program budget comes from: a. State Budget; b. Grants or donations, and / or other funding sources that are legitimate but not binding. ${ }^{12}$

\section{Management of providing legal aid}

There are six principles in Act No 16 of 2011 which are used as the basis for the implementation of legal aid program, namely: a) justice; b) equality before the law: c) transparancy: d) effisiency; e) effectiveness; f. accountability.

These principles in legal aid program must be able to support the achievement of its objective, namely access to justice for poor people equally. ${ }^{13}$ By using a target or objective-based management as stated by Peter F.Drucker ${ }^{14}$ there must be a strategic plan and work program of the organization of legal aid that is directed towards the goal. The role of the manager is focused on the achievement of the goal: the legal aid beneficiaries gain equitable access to justice.

Of the provisions contained in Act 16 of 2011, there are some things that less to support the achievement of these objectives, namely: a. the scope of legal aid is not extensive, which only focus on legal aid for those who can not afford economically, and does not include legal aid to fight injustice structurally, as well as pro bono litigation; $b$. the requirement for legal aid institute are quite hard and more emphasis on formality, make it less effective or less conducive to support the achievement of the optimum goal, both in the quantity of legal aid institute that is considered to pass the certification test as well as the quality of legal assistance provided. As specified in the Act No 16 of 2011, legal aid institute that can provide legal assistance must meet the requirements as specified and supervised its implementation by the government. Terms as legal aid providers place more emphasis on formality,

\footnotetext{
${ }^{11}$ See the provision in $\mathrm{r} 6(2)$

${ }^{12}$ See the provision in $\mathrm{r} 16(1)$

${ }^{13}$ See $r 3 a$ and c of Act 16 of 2011.

${ }^{14}$ Drucker Petter F. An Introductory View of Management, Harper \& Row, Publiceher Inc New York 1977, p.157.
} 
namely: $\left.{ }^{15} 1\right)$ incorporated ; 2) accredited by the law; 3) have a permanent office or secretariat; 4) has the board; 5) has the legal aid program. Of these requirements, only strong legal aid institutions will have more opportunities to receive assistance budget. Due to be incorporated as well as for the preparation of certification every three years it needs great cost. Only the institution who has title to the land and buildings that can have a permanent office. Terms of incorporated legal aid will also preclude legal aid institute of the Faculty of Law and agencies, such as the legal aid post, in legal aid participation. These conditions provide opportunities for the wrong target, such as: giving legal aid funding to institute that entirely has a new 'legal aid programs' and doesn't provide the program yet but even passed the certification, rather than giving legal aid funding to long-working legal aid institute that is un-incorporated, or does not qualify for certification, or does not have a permanent office. c. the government acts only as the resourcer of fund and the supervisor, not the encourager. There is no role of government to encourage and facilitate the establishment of legal aid agencies, such as in remote areas where no legal aid agencies. How to access legal aid for the poor people in these remote areas if there is no legal aid institution or social organization there? While r6(2) Act No 16 of 2011 stipulates that the provision of legal aid organized by Ministers and implemented by legal aid institution or social organization. The limited role of the central government can thus lead to less optimum access to justice for the poor, especially in remote areas. Local government agency as one of the elements involved in the administration of legal aid also limited its role, which can only allocate legal aid fund but not mandatory. ${ }^{16}$ The role of local government then becomes weak, since it is not mandatory to allocate legal aid fund, ${ }^{17}$ which results less optimum access to justice for the poor. d. Implementation of legal aid by the Government can rise to a conflict of interest or abuse of power when the Government is the opossant in a case with the poor.

\section{Part Two. The Problem in Pratices}

Many litigants are hopeless about the effectiveness of the Act No16 of 2011 in order to overcome the problem of legal aid and to serve legal assistance to the poor

\footnotetext{
${ }^{15}$ See the provisions of $\mathrm{r} 8(2)$

${ }^{16}$ See the provision of r19(1) Act No 16 of 2011.

${ }^{17}$ Only a little of local government that compose the regulation on legal aid. Include them is Sinjai, South Sulawesi (http://www.sigapbencana-bansos.info/berita/3192-sinjai-pemkab-bentuk-perda-bantuan-hukumgratis.html, 9 April 2012.
} 
optimally. At the pratices, that legal aid scheme has not been much enjoyed yet by the poor. ${ }^{18}$ Here are some factors.

\section{Minimum budget from the Government}

Once the litigant wants to file civil lawsuit, he/she has to retain some money to be paid to the court, as the court-cost. The court-cost that should be paid included: the cost of commencing of lawsuit, confiscation cost, property inspection cost, subpoena cost, non monetary judgement's enforcement, monetary judgement's enforcement, 'payment-in' fee, photo-copying of decision. ${ }^{19}$

The provision concerning with the court-cost in civil litigation are constituted in Het Herziene Indonesisch Reglement, Staatblad No 44 of 1941 (HIR, Ind) and Reglement Buiten Gewijsten, Staatblad No 227 of 1927 (Rbg, Ind). ${ }^{20}$ Based on r121(4) of HIR or $\mathrm{r} 145(4)$ of $\mathrm{Rbg}$, the court-cost should be paid in the beginning by the plaintiff, as the initiator.

The Supreme Court provides that the court-cost is regulated by each court. ${ }^{21}$ Based on this provision, each court may then make a regulation relating to the court-cost components and scale, regarding to the circumstances of each court's region. The general component and scale of the court-cost in civil lawsuits can be studied from two original court' regulations, as shown comparatively in Table 1 below.

Table 1

The component and scale of the court-cost in civil lawsuit ${ }^{22}$

\begin{tabular}{|c|c|c|c|}
\hline The Component & $\begin{array}{c}\text { The fare in Yogyakarta } \\
\text { General Court }\end{array}$ & $\begin{array}{l}\text { The fare in North- } \\
\text { Jakarta General Court }\end{array}$ & Annotation \\
\hline $\begin{array}{l}\text { Commencing of } \\
\text { lawsuit }\end{array}$ & $\operatorname{Rp} \quad 510.000$ & Rp 615.000 & \\
\hline Confiscation cost & Rp 1.050.000 & $\operatorname{Rp} \quad 600.000$ & Paid if needed \\
\hline $\begin{array}{l}\text { Property inspec- } \\
\text { tion cost }\end{array}$ & $\operatorname{Rp} \quad 500.000$ & Rp 1.000 .000 & Paid if needed \\
\hline Subpoena cost & $\begin{array}{lr}R p & 50.000 \text { and } \\
R p & 100.000\end{array}$ & Rp 180.000 & $\begin{array}{l}\text { Each addi- } \\
\text { tional party }\end{array}$ \\
\hline
\end{tabular}

${ }^{18}$ In Sleman General Court, $57 \%$ of the poor litigants in criminal cases enjoyed the legal assistance but there was no data about the legal aid program in civil cases. See, Elisabeth Sundari, the Implementation of Act No 16 of 2011 in Sleman General Court, Research Report, 2012.

${ }^{19}$ See, r20(3) of Appendix-A of SEMA No 10 of 2010 (Ind)

${ }^{20}$ These two Reglement are the old provisions made by Netherland Colonization Authority in Indonesia, that concordancely adopted from Netherland' own. Now are still be valid for Java and Madura (by HIR), and out of Java and Madura (by Rbg). None of these Reglements provide class proceeding, since those were from civil law system jurisdiction.

${ }^{21}$ See, r3(2) of the Supreme Court Rule No 2 of 2009 (Ind).

${ }^{22}$ Based on Penetapan Ketua Pengadilan Negeri Yogyakarta Nomor : W13-UI/815/Hk.02/Iii/2011 (Ind); also Penetapan Ketua Pengadilan Negeri Jakarta Utara Nomor: W10-U4/2767/HK.02/VI/2010 (Ind). 


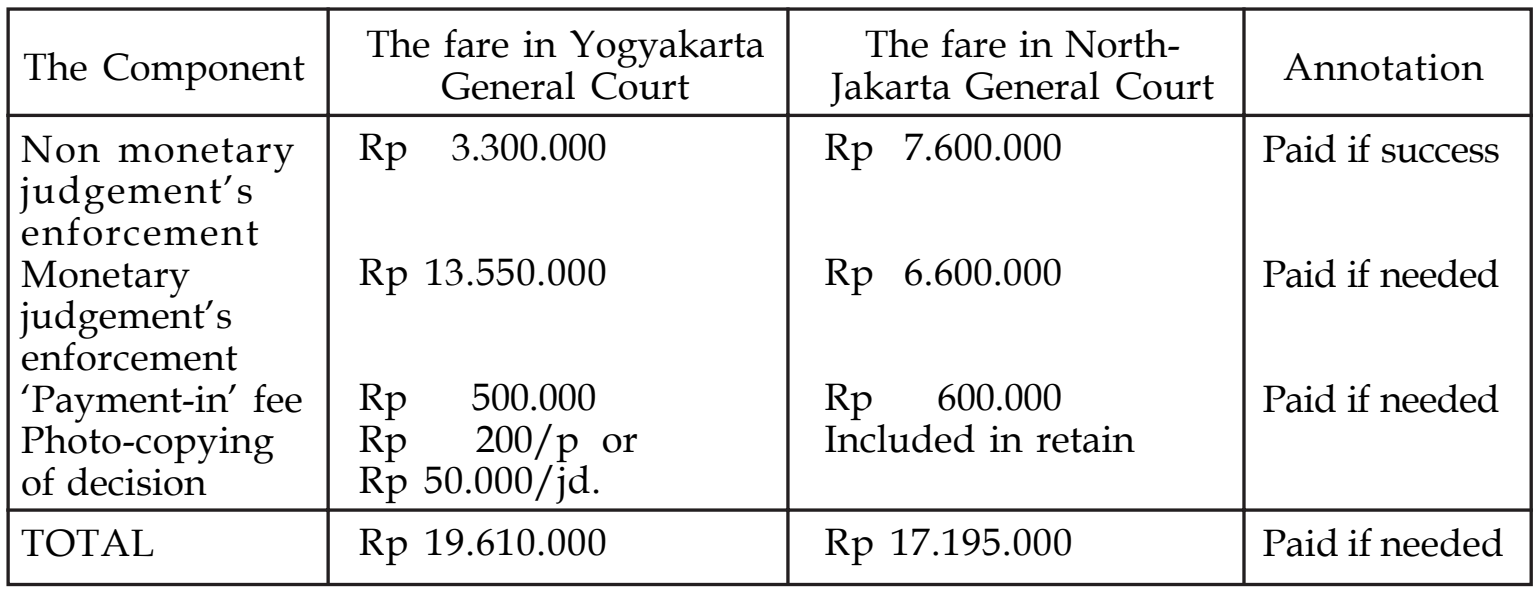

Based on that scale, the cost to commence lawsuit is $47.67 \%$ of the Jakarta minimum wage of worker per-month, that is Rp. 1. 290.000, ${ }^{23}$ and $63.11 \%$ of the Jogjakarta minimum wage of worker per-month, that is Rp. 808.000. ${ }^{24}$ Accordingly, it can be said that the filing cost of civil lawsuits is still daunting for the poor litigants.

Based on the scale above, the plaintiff has to retain approximately Rp. 510.000 to Rp. 615.000 in the beginning to bring civil lawsuit, or about $47,67 \%$ to $63,11 \%$ of their wage per-month. At the other side, one of the principle of court procedure is to abandon the defficiency of the administration of justice. ${ }^{25}$ With this in mind, the efficiency of bringing lawsuit ought to be borne in mind.

The judge has a role to conduct the judicial process efficiently. Indonesia has the principle of 'the judge should become involved', that implicitly can be seen in r4(2) of Act No 48 of 2009, that states: 'The court should assist litigants and make every effort to overcome all obstacles to meet the aims of a simple, speedy, and cheap administration of justice'. R132 of HIR or r156 of The Rbg, also expresses that principle, which states that '[t]he judges should assist litigants who do not understand the procedures in filing a lawsuit'. These provisions express that the judges have a role to promote the 'efficiency of justice' principle.

The source of funding for legal aid seems good when it is allocated in Government budget. While, how much is allocated, this is a classic problem. In fact, the budget in legal aid scheme cannot be relied upon, since the total budget to be shared for all programmes is very limited. For example, in 2010 the total budget

\footnotetext{
${ }^{23}$ See, r1 of the Governor of Jakarta's Decision No 196 of 2010 (Ind) about the scale of DKI Jaya' regional wage

${ }^{24}$ See, Governor of Yogyakarta Special Province Decision No 270/KEP/2010 (Ind) about the scale of DIY' regional wage

${ }^{25}$ See, r2(4) of Act No 48 of 2009.
} 
for legal aid in Indonesia was Rp. 3.250.000.000. ${ }^{26}$ As provided, it should be shared across all jurisdictions (one general jurisdiction and three limited jurisdictions) for a three scheme programme: providing legal aid offices, paying the duty lawyers, and bearing the court-costs in 'no-charge' proceeding for poor litigants. If it is shared in the same proportion, each scheme will recieve Rp. 1.083.333.333. If the 'no-charge programme' receives Rp1 .083.333.333, that should be shared among 678 original courts of general and limited jurisdictions, with each court will only receive Rp. 1. 597.836 in a year. ${ }^{27}$ What can be expected with such a limited budget to assist the cost barrier faced by the poor litigants? One court would receive Rp. 1.597.836, which is insufficient to cover the cost of all civil lawsuit in legal aid scheme.

The Indonesian Government normatively has a good legislation which provides the state responsibility to bear the court-cost in general cases for poor litigants. However, it creates an expectation but cannot be met, since the budget is very limited in implementation.

\section{Advocates avoided their obligation}

Professional Advocate through r22 paragraph (1) of Advocate Act, No 18 of 2003 are required to provide legal assistance free of charge (pro bono) to clients who can not afford. In fact, there were only some of lawyers who are willing to provide legal assistance free of charge. R22 paragraph (2) of Act No 18 of 2003 stipulates that the provision on the requirements and procedure for the free of charge legal assistance as referred in r22 paragraph (1), shall be further regulated by Government Regulation. The regulation has not been enacted yet up till now.

Based on the research, ${ }^{28}$ even obliged, many advocate didn't fullfill their duty to provide legal assistance free of charge to clients who can not afford. Two main factors namely the lack of interested incentives and lack of sanctions.

\section{The absence of interested incentives}

Time, effort and cost of necessary to provide consultation, assistance and/or legal defense in a case is much enough. The provision of legal assistance free of charge becomes less intereting to professional advocates since the incentive was insufficient

${ }^{26}$ Available at http://www.badilum.info/images/stories/ortala/LAPTAH_Ditjen Badilum 2010 part 1.pdf, 10 October 2011.

${ }^{27}$ For the total number all of the courts, see http://litbangdiklatkumdil.net/direktori-pengadilan/, 14 November 2011.

${ }^{28}$ See, Elisabeth Sundari, the Implementation of Act No 16 of 2011 in Sleman General Court, Research Report, 2012. 
to cover the entire cost for such operations in order to provide a defense. They would prefer to defend a case with enough cash honorarium or more.

From the lawyers' organization, there is no budget allocations that are fixed to support the implementation of the obligation to provide legal assistance free of charge. Although r8(c) and r11 of Appendix-A of SEMA No 10 of 2010 provides that "The provision and the implementation of the legal aid budget in the general jurisdiction are included for ...the cost assistance for the duty-lawyer..", in fact, the Government budget in legal aid scheme cannot be relied upon, since the total budget to be shared for all programmes is very limited.

\section{The absence of sanction}

If the lawyer is not willing to provide legal assistance free of charge as required by Act No18 of 2003 with a variety of reasons that can be made, there are no sanctions. The Ethic Code of each advocates organization did not set sanction for member who is not willing to provide legal assistance free of charge. ${ }^{29}$ The absence of sanction does not support the fulfillment of the rights of the poor to obtain legal assistance free of charge.

In the law governing the Company, there are obligation for companies to implement CSR (Corporate Social Responsibility) accompanied by sanctions, which is attached to the existence of the company in question. ${ }^{30}$ The existence of sanction would support the effectiveness of CSR obligation. Can the provision of the obligation to provide legal aid for free of charge be analogous to the social responsibility of the lawyers, along with sanction for violator? As Paton viewed, ${ }^{31}$ the existence of strict sanction for a norm will support the effectiveness of the norm.

\section{Conclussion and Proposals}

From the analysis of the legal policies relating to legal aid and its practices, it can be concluded that the legal aid policy and its practices in Indonesia didn't conduct the optimum result to provide equitable access to justice for the poor, both economically and structurally. There are some proposals that may be submitted as an effort to

\footnotetext{
${ }^{29}$ See, The Ethic Code of IKADIN, AAI, IPHI, HAPI, SPI, AKHI, HKHPM.

${ }^{30}$ See, Act No.40 of 2007 on Incorporated Company; Government Regulation No.47 of 2012, on Social and Environmental Responsibility of Incorporated Company; Act No.25 of 2007 on Investment; Act No.. 32 of 2009 on the Protection and Management of the Environment; Act No.. 22 Year 2001 on Oil and Natural Gas

${ }^{31}$ Paton said that if the law is a command or prohibition, the strict sanctions are the characteristic of the law that should be there. See, George White Paton, A Text Book of Jurusprudence, 1951.
} 
guarantee the fulfillment of equal access to justice, namely: 1. extending the scope of legal aid. Not only for those who are economically poor, but even for those who are structurally poor; 2 . sufficient budget allocation. The average number of cases that need to be assisted by legal aid scheme in any court can be estimated each year. The amount of appropriate incentives for lawyers who provide legal assistance can be calculated. The amount of budget allocation to support the achievement of equitable access to justice can be determined then by these two things. The right to access to justice is a part of human rights, so that the local government is also responsible to allocate the budget to fulfill that human right in their Region; 3. organization management of legal aid that support the achievement of the objectives. Legal aid should be obliged, not only to legal aid institution, but also to professional advocates when they are appointed; 4 . the formalistic requirements to obtain legal aid scheme should be directed to the terms that substantively support the achievement of the goals or the objectives to provide legal aid, such as: only the institution or profesional advocate who has done legal aid program activities that would have an incentive of legal aid fund. Terms of legal incorporated, accreditation, permanent office, can become facultative requirement; 5 . the quality of legal aid services and the implementation of the performance should be evaluated based on the clients or recipient investigation. ${ }^{32}$ The useless of legal aid fund, can be prevented by implementing the proposal principle: there the case, there the incentive; 6 . coordinative and facilitative institutional support. Due to the fact that legal assistance is also given in the judicial process, the role of law enforcement institutions in the implementation of legal assistance should also be provided in the legal aid provision to support the more comprehensive and coordinative implementation.

Concerning to the reversal operation of legal aid from Supreme Court to the Government, there are two alternatives to prevent conflict of interest or abuse of power, namely: a. retruning the provider of legal aid scheme to the judiciary, or b. creating the provision which guaranting the independence in giving the legal aid fund, especially in the case that involving the poor and the Government as plaintiff and defendant.

Government (or judiciary) should push and facilitate the establishment of legal aid institutes in remote areas, for example, by setting up the Legal aid Post in court.

${ }^{32}$ In many States of the United States of America, monitoring of the performance of lawyers is conducted jointly by the advocates organization, consumers, and the Supreme Court (See, Todung Mulya Lubis, Long Road for Human Rights, Gramedia Press, Jakarta, 2005, p.104) 
This will become consistent with the provisions of r6 paragraph (2) of Act No16 of 2011 which states that legal aid providers conducted by the Minister and held by legal aid institutes or social organization.

\section{References}

Black, Henry Campbell, Black's law Dictionary, Sixth edition, St.Paul Minn, West Publishing Co, 1991.

Drucker, Petter F. An Introductory View of Management, Harper \& Row, Publiceher Inc New York, 1977.

Horngren, Charles T, Cost ccounting: A managerial Emphasis, Firth Edition. Englewood Cliffs: Prentice-Hall, Inc.,1982.

Huijbers, Theo, Filsafat Hukum dalam Lintasan Sejarah, Penerbit Kanisius, Yogyakarta, 1982.

LBH Jakarta, Bantuan Hukum: Akses Masyarakat Marjinal Terhadap Keadilan, LBH Jakarta, 2007.

Lubis, Todung Mulya, Jalan Panjang Hak Asasi Manusia, Peneribit Gramedia, Jakarta, 2005.

Nasution, Adnan Buyung, History Legal assistance in Indonesia: Legal Aid: Access to Justice for Marginal Society, the Jakarta Legal Aid, Jakarta, 2007.

George White Paton, A Text Book of Jurusprudence, 1951.

Sundari, Elisabeth, the Implementation of Act 16 of 2011 in Sleman General Court, Research Report, 2012.

W.J.S Poerwadarminta, Kamus Umum bahasa Indonesia, Balai Pustaka, 1996.

(http:/ / www.sigapbencana-bansos.info/berita/3192-sinjai-pemkab-bentuk-perdabantuan-hukum-gratis.html,

http://www.badilum.info/images/stories/ortala/LAPTAH_Ditjen_Badilum_2010 _part_1.pdf,

http://litbangdiklatkumdil.net/direktori-pengadilan

Universal Declaration of Human Rights 1948 (UDHR)

1945 Constitution (Second Amandment)

Het Herziene Indonesisch Reglement, Staatblad No 44 of 1941 (Ind)

Rechts Reglement Buiten Gewijsten, Staatblad No 227 of 1927 (Ind)

Act 8 of 1981 on Criminal Procedure Code

Oil and Natural Gas Act, No. 22 of 2001 
Advocates Act, No. 18 of 2003

Investment Act, No. 25 of 2007

Incorporated Company Act, No. 40 of 2007

Protection and Management of the Environment Act, No. 32 of 2009

Fundamental of the Judiciary Power Act, No 48 of 2009 (Ind)

Second Amandement Act No 2 of 1986 (Ind) on the General Court,Act No 49 of 2009 (Ind);

Second Amandement Act No 7 of 1989 (Ind) on the Religion Court, Act No 50 of 2009 (Ind);

Second Amandement Act No 5 of 1986 (Ind) on the Administrative Court, Act No 51 of 2009 (Ind).

Legal Aid Act, No. 16 of 2011

Government Regulation No. 47 of 2012 on Social and Environmental Responsibility of Incorporated Company

Supreme Court Rule No 2 of 2009 (Ind).

SEMA No. 10 of 2010 